\title{
Developing Threshold Parameters to Administer Live Vaccines in Cellular Immunodeficiency: A Survey of Practicing Clinical Immunologists
}

Justine M. Ade ( $\sim$ ade.justine@mayo.edu )

Mayo Clinic Minnesota https://orcid.org/0000-0003-1592-4276

Avni Joshi

Mayo Clinic Minnesota

\section{Research Article}

Keywords: Live vaccine, Immunodeficiency

Posted Date: March 12th, 2021

DOl: https://doi.org/10.21203/rs.3.rs-274955/v1

License: (c) (i) This work is licensed under a Creative Commons Attribution 4.0 International License. Read Full License 


\section{Abstract}

Live vaccines are contraindicated in patients with severe cellular immunodeficiencies while guidelines regarding the administration of live vaccines in patients with more mild disease are ill-defined. We sought to decipher different parameters used by practicing immunologists for the administration of live vaccines in cellular immunodeficiency patients. A 27-question survey assessing clinical and laboratory threshold parameters used in the administration of live vaccines to immunodeficient patients was distributed to practicing clinicians specializing in immune deficiencies. There were 83 survey respondents, $65 \%$ identified as female, and $71 \%$ were based in the United States. Allergy / Immunology and Immunodeficiency were the most common identified specialties, accounting for $84 \%$ of respondents. Most clinicians did administer live vaccines to patients with humoral (54/67; 80.6\%), cellular (41/67; $61.2 \%)$, and combined diseases $(37 / 67 ; 55.2 \%)$. Most clinicians who reported giving live vaccines to patients with immune deficiencies considered a threshold CD4 count of $\geq 400 \mathrm{cells} / \mathrm{mm} 3$ (MMR 48/60 [80\%], Varicella $42 / 53$ [79\%], Rotavirus $40 / 45$ [88.89\%]), a CD8 count of $\geq 250$ cells/mm3 (MMR 30/39 [76.92\%], Varicella 29/37 [78.34\%], Rotavirus 27/34 [79.41\%]), and normal mitogen function (MMR 44/53 [83.02\%], Varicella 40/48 [83.33\%], Rotavirus 37/40 [92.5\%]). Using these survey results, we propose a treatment threshold of using CD 4 count of $\geq 400$ cells $/ \mathrm{mm} 3$, a CD8 count of $\geq 250$ cells $/ \mathrm{mm} 3$, and normal lymphocyte proliferative responses to mitogen. Future studies are needed to determine clinical efficacy and safety using these thresholds.

\section{Introduction}

In recent years, there has been evidence of waning herd immunity due to decreased rates of immunization by the general population with increasing rates of vaccine preventable disease [1]. The Center for Disease Control and Prevention (CDC) guidelines recommend the administration of live vaccines with rotavirus at 2 and 4 months of age followed by a possible third dose at 6 months of age depending on the formulation [2]. The first doses of MMR and varicella are recommended between 12-15 months of age followed by a second dose at 4-6 years [2]. Children with a history of combined immunodeficiency are especially susceptible to vaccine associated disease [3]. However, live vaccines have been reported to be well tolerated in specific cohorts of HIV patients and DiGeorge syndrome patients who have milder immune deficiency [4-6]. Guidelines regarding the administration of live vaccines in other immunodeficiencies with evidence of T-cell lymphopenia, however, are more ill-defined leaving clinicians a difficult decision in determining which patients can be given live vaccines safely. Often times, clinical decisions are extrapolated from outcomes in HIV and DiGeorge syndrome cohorts. Additionally, clinicians may look to available guidelines as per the Infectious Diseases Society of America (IDSA) or the CDC's Advisory Committee on Immunization Practices (ACIP). However, these guidelines are not comprehensive and recommendations are conflicting $[7,8]$.

Given the lack of clear guidelines in most specific combined immune deficiency disorders, there is a need for clarification on when live vaccines can safely be administered to these patients. Additional clarification may equip providers with confidence and increase rates of vaccination in this vulnerable 
group of patients. We aimed to survey factors utilized by clinicians who care for immunodeficient patients when deciding to administer live viral vaccines.

\section{Methods}

A 27-question survey assessing clinical and laboratory parameters was used to determine whether live vaccines are administered in clinical practice to immunodeficient patients with T-cell lymphopenia and / or combined immunodeficiencies. The survey was then distributed to members of the Clinical Immunology Society (CIS) listserv after approval. We included the following variables in the study: CD4 and CD8 T cell counts in addition to T-cell functional studies such as antigen, mitogen, and anti-CD3 assays. If a clinician used a variable in decision making but had a threshold other than a normal level, we asked the clinician to specify a threshold for the administration of measles, mumps and rubella (MMR), varicella, and rotavirus individually. The full survey is available in Appendix 1. Data was then analyzed to determine parameters used amongst clinicians when considering the administration of live vaccines to immunodeficient patients. Categorical patient characteristics were compared between groups using a two-sided chi-square test.

\section{Results}

There were 83 total survey respondents, $65 \%$ identified as female, and were of varying ages. Allergy / Immunology and Immunodeficiency were the most common identified specialties, accounting for $84 \%$ of respondents. Seventy-one percent of providers were based in the United States, followed by $7.5 \%$ of clinicians based in Canada. Table 1 shows the demographic characteristics of the cohort of survey responders.

Table 2 illustrates general immunization practices. Eighty-three percent of the cohort (69/82) reported administering live vaccines to immunodeficient patients. Most clinicians gave live vaccines to patients with humoral (54/67; 80.6\%), cellular $(41 / 67 ; 61.2 \%)$, and combined diseases $(37 / 67 ; 55.2 \%)$. The most frequently used parameters included the CD4 count and T cell functional studies in 72/81 (88.89\%) and $70 / 81$ (86.42\%), respectively. CD8 and absolute lymphocyte counts were less frequently used at 29/81 $(35.80 \%)$ and $44 / 81(54.32 \%)$, respectively. Of the T-cell functional studies, a majority used mitogen proliferation assays in $47 / 70(67.14 \%)$ while antigen proliferation assays $18 / 70(25.71 \%)$ and anti-CD3 assays $5 / 70(7.14 \%)$ were less frequently used. If administering live vaccines, there was a trend to administer MMR and varicella separately 52/79 (65.82\%) while 20/79 (25.3\%) reported giving them in combination. Of those who did administer MMR and varicella vaccines separately, $37 / 52(71.2 \%)$ administer varicella first followed by MMR if varicella vaccine was well tolerated. Forty-eight of eighty clinicians (60.0\%) reported assessment of seroconversion to vaccination after live vaccine administration.

We then assessed parameters for administration of individual vaccination to MMR, varicella, and rotavirus (Table 3). CD3 and CD8 parameters were similar for the administration of MMR, varicella, and rotavirus. While the use of CD4 was less frequently used for rotavirus. The majority of clinicians did not 
use CD3 count (53-58\%) as a parameter to administer MMR, Varicella, or rotavirus vaccines, although 24$34 \%$ of clinicians would consider administering it if was normal. Of those who did consider administering vaccines when the CD3 count is near normal (11-18\%), the lowest threshold indicated was $>/=500$ cells/mm3. The majority of clinicians thought that CD4 count was an important parameter for the administration of MMR, Varicella and rotavirus. Of those who use this parameter, $25-33 \%$ would consider administering the vaccines if CD4 count was normal and an additional $38-56 \%$ would administer the vaccines when the CD $4 \mathrm{~T}$ cell counts were near normal with the lowest threshold at $>/=200 \mathrm{cells} / \mathrm{mm} 3$ but the majority administered vaccines if $>/=400 \mathrm{cells} / \mathrm{mm} 3$. Only $15-28 \%$ of clinicians reported not using the CD4 count as a parameter. CD8 count was used as an infrequent parameter used in $<30 \%$ of the survey cohort, with $42-46 \%$ of clinicians reporting not using this parameter in administrating MMR, varicella, or rotavirus. For those who would administer vaccines at near normal level CD8 T cell counts (30-46\%), the lowest threshold reported was $>/=100$ cells $/ \mathrm{mm} 3$ but with a majority administering if greater than 250 cells/mm3.

Beyond the numeric assessments, we also assessed whether $\mathrm{T}$ cell functional studies were used as a parameter for the administration of live vaccines (Table 3). Overall, T cell functional studies were less frequently used as a threshold for administration of rotavirus. For mitogen testing, the majority (59-62\%) of respondents would consider giving when normal, while $24-35 \%$ reported not using this as a parameter when administering MMR, varicella, or rotavirus while. Other T-cell functional studies were utilized less frequently with only $20-30 \%$ and $9-15 \%$ of clinicians reporting they would consider giving live vaccines if these parameters were normal for antigen proliferation and anti-CD3 testing respectively.

Lastly, we surveyed clinicians regarding vaccine related adverse events. Nine of fifty-four respondents (16.7\%) reported having a patient who experienced vaccine related adverse events. Two reactions (2/9; $22.2 \%)$ resulted in non-specific fever while seven of the reactions $(7 / 9 ; 77.7 \%)$ were identified as being consistent with infections resulting from the vaccine virus (e.g. rubella or varicella rash). Out of these 7 vaccine induced infections, five of them $(5 / 7 ; 71.4 \%)$ occurred after receiving varicella immunization.

\section{Discussion}

Our results show the heterogeneity in the practicing clinicians for the administration of live vaccines in patients with cellular immune deficiency disorders. This is likely a reflection of insufficient data available and most recommendations are based on expert opinions. In recent years, there has been evidence of waning herd immunity due to decreased rates of immunization by the general population [1]. Children with a history of combined immunodeficiency are especially susceptible to these vaccine preventable disease, likely contributed in part by the inherent shortcomings of their immune system, but also due to the fact that there may hesitancy in administering live vaccines in many of these patients, especially the ones with severe $T$-cell immunodeficiencies [3]. Guidelines regarding the administration of live vaccines in patients with more mild immunodeficiency, however, are ill-defined leaving clinicians with the difficult choice of deciding which immune deficient patients are able or not able to receive them. 
Given that there is insufficient data regarding the administration of live vaccines in specific combined immunodeficiencies, clinicians draw information from several resources when deciding to give live vaccines to patients with milder defects. One source is to extrapolate data from studies in mild HIV and partial DiGeorge syndrome cohorts [4-6]. Al-Sukaiti and Grunebaum reported no moderate or severe reactions in a cohort of 80 DiGeorge patients after administration of MMR in patients with a CD4 count of $>500$ T cells / mm3. Mild reactions occurred in only 6 patients [9]. There have also been some reports of safely administering varicella vaccine in children with a CD4 T cell count $>200$ cells $/ \mathrm{mm} 3$ in addition to giving MMR in HIV patients with $>15 \%$ CD4 T cells and a CD4 count of $>200$ cells/mm3 [10-14].

Furthermore, common guidelines that clinicians might reference include those from the IDSA and ACIP. Unfortunately, these guidelines differ slightly when it comes to recommendations for patients with milder combined disease [15], creating additional uncertainties for the practicing clinician.

The IDSA guidelines support the administration of MMR and varicella vaccine but not combined MMRV in patients with partial DiGeorge syndrome who demonstrate $\geq 500 \mathrm{CD} 3+\mathrm{T}$ lymphocytes/mm3, $\geq 200 \mathrm{CD} 8+$ T lymphocytes $/ \mathrm{mm} 3$, and normal mitogen response. Patients with SCID, DiGeorge syndrome, and other combined immunodeficiencies with T-cell lymphocyte count $<500$ cells $/ \mathrm{mm} 3$ are recommended to avoid all live vaccines. However, in other non-DiGeorge syndrome T-cell defects, the IDSA indicates that extrapolation of data from HIV-infected persons suggests that a CD4 count $\geq 200$ cells $/ \mathrm{mm} 3$ in adults or percentage $\geq 15$ may be reasonable but has uncertain validity [16]. In contrast, the Advisory Committee on Immunization Practices (ACIP) does not recommend administering live vaccines in patients with partial combined immunodeficiencies. Additionally, severe cell-mediated immunodeficiency are considered a contraindication for receipt of live vaccines, however the definition of severe cell-mediated immunodeficiency is lacking [8]. Furthermore, the IDSA recommends against combined MMRV administration and administering MMR and varicella as separate vaccines given that MMRV has a higher antigenic load and as such, is more likely to be associated with adverse effects such as fever and febrile seizure [16].

In our study, most clinicians reported comfort with live vaccine administration to mild immunodeficient patients. The majority $(80 \%)$ of respondents did administer live vaccines to patients with humoral defects but this decreased to $61 \%$ in those with cell mediated defects and $55 \%$ to those with combined defects. These findings are not unexpected given that most live and inactivated vaccines can be tolerated in patients with non-severe humoral immunodeficiencies while the benefit/safety of administration of these vaccines in patients with T-cell deficits is more questionable [17]. Clinicians also reported that the most frequently used parameters when making the decision to administer live vaccines include the CD4 count and functional T-cell studies, which was used amongst $88 \%$ and $86 \%$ of clinicians respectively. In contrast, the CD8 count was used amongst only $54 \%$ of clinicians - a surprising finding given that the CD8 count is indicated as an important parameter for the administration of live vaccines in patients with partial T cell defects and partial DiGeorge syndrome in the Red Book and IDSA guidelines respectively $[7,18]$. 
Our aim through this survey was to create a threshold parameter, that the practicing clinician may use as a guideline when they encounter the clinical conundrum of whether or not to administer live vaccines in cellular immune defects. Our results indicate that most clinicians who do administer live vaccines to patients with cellular immune deficiencies would confidently consider administration at a CD 4 count of $\geq$ 400 cells/mm3 (MMR 48/60 [80\%], Varicella 42/53 [79\%], Rotavirus 40/45 [88.89\%]), a CD8 count of $\geq 250$ cells/mm3 (MMR 30/39 [76.92\%], 29/37 [78.34\%], Rotavirus 27/34 [79.41\%]), and normal mitogen function( MMR 44/53 [83.02\%], Varicella 40/48 [83.33\%], 37/40 [92.5\%]) (Table 4). Based on these responses, clinicians who are considering the administration of live vaccines to patients with cellular immune deficiency may wish to consider these threshold parameters.

Although the administration of live vaccines in patients with partial DiGeorge syndrome and low-level immunosuppression HIV has been well tolerated [4], complications of live viral vaccines have also been reported including chronic rotavirus infection [19], disseminated measles [20], and varicella [21,22] in T-cell deficient patients. One last observation from our findings includes nine respondents reporting having a patient who experienced a vaccine related adverse event. Seven of these reactions were identified as being consistent with infections resulting from the vaccine virus. Five of these were from varicella, two of which required hospitalization. One patient was described having granulomatous skin lesions which were positive for vaccine strain rubella. The rest were described as rashes (ie. rubella rash, varicella rash). Lymphocyte counts and function studies in patients who had a reaction were not reported individually.

This study does have several limitations. Although there are a number of other live vaccines, our focus was on MMR, varicella, and rotavirus given that these are the first vaccinations to be administered in childhood and are more frequently given in the general population. With that said, our study is naturally focused more toward pediatric patients. We cannot exclude that those caring primarily for adults may practice differently and have different threshold parameters. Additionally, our study cannot comment on the safety of these threshold parameters. While there were 9 respondents who reported a previous vaccine related reaction, the goal of our study was not to evaluate the safety of administering vaccines but rather to identify a threshold for administering them based on the experiences of clinician experts in immunodeficiency. Lastly, the majority of our respondents practice primarily in the United States, limiting the generalizability of our findings.

\section{Conclusions}

Our study is the first to describe clinically used thresholds for the administration of live vaccines in T-cell lymphopenia and combined immunodeficiencies among providers who care for immunodeficient patients. A majority of clinicians do administer live vaccines to mild cellular immunodeficient patients, however, these thresholds for administration vary. CD4 T cell counts and mitogen proliferation studies were the most commonly used parameters amongst clinicians. A unifying standard for administration is needed amongst immunologists, infectious disease specialists, and pediatricians. Further clarification may improve vaccination rates amongst patients with mild T-cell defects and combined immunodeficiencies. Several additional studies may be helpful including those that delineate the 
practices amongst immunologists, infectious disease specialists, and general practitioners, insight into international practices, inclusion of other live vaccines, vaccine administration safety, and lastly whether there are differences amongst adult and pediatric providers.

To our knowledge, ours is the only study evaluating clinician reported thresholds for the administration of live vaccines to patients with cellular immunodeficiencies and may pave the way to help standardize our approach to vaccinating patients with cellular immune deficiency disorders.

\section{Declarations}

Acknowledgement: We would like to thank the Clinical Immunology Society (CIS) for helping with the survey and allowing us to survey its members through the Listsserv.

\section{Sources of Support/Funding: None}

Conflicts of interest: None declared.

Author contributions: All authors contributed to the study conception and design. Material preparation, data collection and analysis were performed by Justine M. Ade, MD and Avni Joshi, MD. The first draft of the manuscript was written by Justine M. Ade, MD and all authors commented on previous versions of the manuscript. All authors read and approved the final manuscript.

Availability of data and material: The datasets generated during and/or analyzed during the current study are available from the corresponding author on reasonable request.

Code availability: Not applicable

\section{References}

1. Medical Advisory Committee of the Immune Deficiency F, Shearer WT, Fleisher TA, Buckley RH, Ballas Z, Ballow M, et al. Recommendations for live viral and bacterial vaccines in immunodeficient patients and their close contacts. J Allergy Clin Immunol. 2014;133(4):961-6.

2. Centers for Disease Control and Prevention Immunization Schedules. https://www.cdc.gov/vaccines/schedules/hcp/imz/child-adolescent.html. January 5, 2021.

3. Bakare N, Menschik D, Tiernan R, Hua W, Martin D. Severe combined immunodeficiency (SCID) and rotavirus vaccination: reports to the Vaccine Adverse Events Reporting System (VAERS). Vaccine. 2010;28(40):6609-12.

4. Hofstetter AM, Jakob K, Klein NP, Dekker CL, Edwards KM, Halsey NA, et al. Live vaccine use and safety in DiGeorge syndrome. Pediatrics. 2014;133(4):e946-54. 
5. Scott P, Moss WJ, Gilani Z, Low N. Measles vaccination in HIV-infected children: systematic review and meta-analysis of safety and immunogenicity. J Infect Dis. 2011;204 Suppl 1:S164-78.

6. Aurpibul L, Puthanakit T, Sirisanthana T, Sirisanthana V. Response to measles, mumps, and rubella revaccination in HIV-infected children with immune recovery after highly active antiretroviral therapy. Clin Infect Dis. 2007;45(5):637-42.

7. Rubin LG, Levin MJ, Ljungman P, Davies EG, Avery R, Tomblyn M, et al. 2013 IDSA clinical practice guideline for vaccination of the immunocompromised host. Clin Infect Dis. 2014;58(3):e44-100.

8. National Center for I, Respiratory D. General recommendations on immunization -- recommendations of the Advisory Committee on Immunization Practices (ACIP). MMWR Recomm Rep. 2011;60(2):1-64.

9. Al-Sukaiti N, Reid B, Lavi S, Al-Zaharani D, Atkinson A, Roifman CM, et al. Safety and efficacy of measles, mumps, and rubella vaccine in patients with DiGeorge syndrome. J Allergy Clin Immunol. 2010;126(4):868-9.

10. Levin MJ, Gershon AA, Weinberg A, et al. Immunization of HIV-infected children with varicella vaccine. J Pediatr 2001;139:305-10.

11. Scott P, Moss WJ, Gilani Z, et al. Measles vaccination in HIV-infected children: systematic review and meta-analysis of safety and immunogenicity. J Infect Dis. 2011; 204(1):S164-S178.

12. McLaughlin $M$, Thomas $P$, Onorato $I$, et al. Live virus vaccines in human immunodeficiency virusinfected children: a retrospective survey. Pediatrics 1988;82:229--33.

13. Onorato IM, Markowitz LE, Oxtoby MJ. Childhood immunization, vaccine-preventable diseases and infection with human immunodeficiency virus. Pediatr Infect Dis J 1988;6:588-95.

14. Palumbo P, Hoyt L, Demasio K, Oleske J, Connor E. Population-based study of measles and measles immunization in human immunodeficiency virus-infected children. Pediatr Infect Dis J 1992;11:100814.

15. Whitaker JA. Immunization Strategies to Span the Spectrum of Immunocompromised Adults. Mayo Clin Proc. 2020.

16. Rubin LG, Myron JL, Ljungman P et al. 2013 IDSA clinical practice guideline for vaccination of the immunocompromised host. Clin Infect Dis 2014; 58(3): e44-e100.

17. Sobh A, Bonilla FA. Vaccination in Primary Immunodeficiency Disorders. J Allergy Clin Immunol Pract. 2016;4(6):1066-75.

18. American Academy of Pediatrics. Immunization and Other Considerations in Immunocompromised Children. In: Kimberlin DW, Brady MT, Jackson MA, Long SS, eds. Red Book: 2018 Report of the Committee on Infectious Diseases. American Academy of Pediatrics; 2018; 72-91 
19. Patel NC, et al., Vaccine-acquired rotavirus in infants with severe combined immunodeficiency. $N$ Engl J Med, 2010. 362(4): p. 314-9.

20. Bitnun A, Shannon P, Durward A, Rota PA, Bellini WJ, Graham C, Wang E, Ford-Jones EL, Cox P, Becker $L$, Fearon M. Measles inclusion-body encephalitis caused by the vaccine strain of measles virus. Clinical Infectious Diseases. 1999 Aug 15;29(4):855-61.

21. Bayer DK, Martinez CA, Sorte HS, Forbes LR, Demmler-Harrison GJ, Hanson IC, Pearson NM, Noroski LM, Zaki S, Bellini WJ, Leduc MS. Vaccine-associated varicella and rubella infections in severe combined immunodeficiency with isolated CD 4 lymphocytopenia and mutations in IL 7 R detected by tandem whole exome sequencing and chromosomal microarray. Clinical \& Experimental Immunology. 2014 Dec;178(3):459-69.

22. Leung J, Siegel S, Jones JF, Schulte C, Blog D, Scott Schmid D, Bialek SR, Marin M. Fatal varicella due to the vaccine-strain varicella-zoster virus. Human vaccines \& immunotherapeutics. 2014 Jan 1;10(1):146-9.

\section{Tables}

Table 1: Respondent Characteristics 


\begin{tabular}{|c|c|c|}
\hline & Responses & $\mathrm{n} / \mathrm{N}(\%)$ \\
\hline \multirow[t]{2}{*}{ Gender } & Male & $28 / 80(35.0 \%)$ \\
\hline & Female & $52 / 80(65.0 \%)$ \\
\hline \multirow[t]{4}{*}{ Age (years) } & $30-39$ & $28 / 78(35.9 \%)$ \\
\hline & $40-49$ & $23 / 78(29.5 \%)$ \\
\hline & $50-59$ & $13 / 78(16.7 \%)$ \\
\hline & Over 60 & 15/78 (19.2\%) \\
\hline \multirow[t]{7}{*}{ Specialty } & Allergy/Immunology & $39 / 80(48.8 \%)$ \\
\hline & Immunodeficiency & $28 / 80(35.0 \%)$ \\
\hline & Allergy/Asthma/Pulmonary & $6 / 80(7.5 \%)$ \\
\hline & Rheumatology & $2 / 80(2.5 \%)$ \\
\hline & HIV/Infectious Disease & $3 / 80(3.4 \%)$ \\
\hline & BMT & $1 / 80(1.3 \%)$ \\
\hline & Hematology & $1 / 80(1.3 \%)$ \\
\hline \multirow[t]{16}{*}{ Country } & United States & $57 / 80(71.3 \%)$ \\
\hline & Canada & $6 / 80(7.5 \%)$ \\
\hline & Spain & $1 / 80(1.3 \%)$ \\
\hline & Japan & $1 / 80(1.3 \%)$ \\
\hline & Netherlands & $1 / 80(1.3 \%)$ \\
\hline & India & $2 / 80(2.5 \%)$ \\
\hline & Australia & $2 / 80(2.5 \%)$ \\
\hline & Sudan & $1 / 80(1.3 \%)$ \\
\hline & Italy & $1 / 80(1.3 \%)$ \\
\hline & Egypt & $1 / 80(1.3 \%)$ \\
\hline & United Arab Emirates & $1 / 80(1.3 \%)$ \\
\hline & Israel & $1 / 80(1.3 \%)$ \\
\hline & Sweden & $2 / 80(2.5 \%)$ \\
\hline & Brazil & $1 / 80(1.3 \%)$ \\
\hline & Mexico & $1 / 80(1.3 \%)$ \\
\hline & Finland & $1 / 80(1.3 \%)$ \\
\hline
\end{tabular}


$\mathrm{n}=$ Number with specific response

$\mathrm{N}=$ Total number of res

Table 2: General Vaccine Preferences

\begin{tabular}{|c|c|c|c|c|c|c|c|}
\hline & \multicolumn{7}{|c|}{ Responses } \\
\hline & \multicolumn{3}{|c|}{ Yes n/N (\%) } & \multicolumn{4}{|c|}{ No n/N (\%) } \\
\hline \multirow{5}{*}{$\begin{array}{l}\text { Give live } \\
\text { vaccines to } \\
\text { immunodeficient } \\
\text { patients }\end{array}$} & \multicolumn{3}{|c|}{$69 / 83(83.13 \%)$} & \multicolumn{4}{|c|}{$14 / 83(16.87 \%)$} \\
\hline & \multicolumn{7}{|c|}{$\S$ Humoral 54/67(80.6\%) } \\
\hline & \multicolumn{7}{|c|}{$\S$ Cellular 41/67 (61.19\%) } \\
\hline & \multicolumn{7}{|c|}{$\S$ Combined 37/67 (55.22\%) } \\
\hline & \multicolumn{7}{|c|}{$\S$ Others 28/67 (41.79\%) } \\
\hline $\begin{array}{l}\text { Check sero- } \\
\text { conversion }\end{array}$ & \multicolumn{3}{|c|}{$48 / 80(60.0 \%)$} & \multicolumn{4}{|c|}{$32 / 80(40.00 \%)$} \\
\hline \multirow[t]{2}{*}{ Give half doses } & \multirow{2}{*}{\multicolumn{3}{|c|}{$0 / 83(0 \%)$}} & \multirow{2}{*}{\multicolumn{4}{|c|}{$\begin{array}{l}83 / 83 \\
(100.0 \%)\end{array}$}} \\
\hline & & & & & & & \\
\hline \multirow{2}{*}{$\begin{array}{l}\text { Vaccination } \\
\text { strategy }\end{array}$} & $\begin{array}{l}\text { MMR } \\
\text { and } \\
\text { Varicella } \\
\text { together }\end{array}$ & $\begin{array}{l}\text { Varicella } \\
\text { first and } \\
\text { if } \\
\text { tolerated } \\
\text { MMR }\end{array}$ & $\begin{array}{l}\text { MMR } \\
\text { first and } \\
\text { if } \\
\text { tolerated } \\
\text { Varicella }\end{array}$ & \multicolumn{4}{|l|}{ Other } \\
\hline & $\begin{array}{l}20 / 79 \\
(25.32 \%)\end{array}$ & $\begin{array}{l}37 / 79 \\
(46.84 \%)\end{array}$ & $\begin{array}{l}15 / 79 \\
(18.99 \%)\end{array}$ & \multicolumn{4}{|c|}{$8 / 79(10.13 \%)$} \\
\hline \multirow[t]{3}{*}{ Parameters used } & CBC-ALC & CD4 & CD8 & $\begin{array}{l}\text { T cell } \\
\text { function } \\
\text { studies }\end{array}$ & Mitogen & Antigen & aCD3 \\
\hline & \multirow{2}{*}{$\begin{array}{l}29 / 81 \\
(35.80 \%)\end{array}$} & $72 / 81$ & $44 / 81$ & $70 / 81$ & \multirow{2}{*}{$\begin{array}{l}47 / 70 \\
(67.14 \%)\end{array}$} & \multirow{2}{*}{$\begin{array}{l}18 / 70 \\
(25.71 \%)\end{array}$} & \multirow{2}{*}{$\begin{array}{l}5 / 70 \\
(7.14 \%)\end{array}$} \\
\hline & & $(88.89 \%)$ & $(54.32 \%)$ & $(86.42 \%)$ & & & \\
\hline
\end{tabular}

$\mathrm{n}=$ Number with specific response

$\mathrm{N}=$ Total number of responses

Table 3: Parameters used for giving MMR, Varicella, Rotavirus 


\begin{tabular}{|c|c|c|c|c|c|c|}
\hline & \multicolumn{2}{|c|}{$\begin{array}{l}\text { Responses n/N(\%) } \\
\text { MMR }\end{array}$} & \multicolumn{2}{|c|}{$\begin{array}{l}\text { Responses n/N(\%) } \\
\text { Varicella }\end{array}$} & \multicolumn{2}{|c|}{$\begin{array}{l}\text { Responses n/N(\%) } \\
\text { Rotavirus }\end{array}$} \\
\hline & No & Yes & No & Yes & No & Yes \\
\hline CD3 count & $\begin{array}{l}40 / 70 \\
(57.14 \%)\end{array}$ & $\begin{array}{l}30 / 70 \\
(42.86 \%)\end{array}$ & $\begin{array}{l}38 / 65 \\
(58.46 \%)\end{array}$ & $\begin{array}{l}27 / 65 \\
(41.54 \%)\end{array}$ & $\begin{array}{l}34 / 63 \\
(53.97 \%)\end{array}$ & $\begin{array}{l}29 / 63 \\
(46.03 \%)\end{array}$ \\
\hline CD4 count & $\begin{array}{l}11 / 71 \\
(15.49 \%)\end{array}$ & $\begin{array}{l}60 / 71 \\
(84.51 \%)\end{array}$ & $\begin{array}{l}13 / 66 \\
(19.70 \%)\end{array}$ & $\begin{array}{l}53 / 66 \\
(80.30 \%)\end{array}$ & $\begin{array}{l}18 / 63 \\
(28.57 \%)\end{array}$ & $\begin{array}{l}45 / 63 \\
(71.43 \%)\end{array}$ \\
\hline CD8 count & $\begin{array}{l}29 / 68 \\
(42.65 \%)\end{array}$ & $\begin{array}{l}39 / 68 \\
(57.35 \%)\end{array}$ & $\begin{array}{l}27 / 64 \\
(42.19 \%)\end{array}$ & $\begin{array}{l}37 / 64 \\
(57.81 \%)\end{array}$ & $\begin{array}{l}29 / 63 \\
(46.03 \%)\end{array}$ & $\begin{array}{l}34 / 63 \\
(53.97 \%)\end{array}$ \\
\hline $\begin{array}{l}\text { Mitogen Function } \\
\text { Testing }\end{array}$ & $\begin{array}{l}17 / 70 \\
(24.29 \%)\end{array}$ & $\begin{array}{l}53 / 70 \\
(75.71 \%)\end{array}$ & $\begin{array}{l}17 / 65 \\
(26.15 \%)\end{array}$ & $\begin{array}{l}48 / 65 \\
(73.85 \%)\end{array}$ & $\begin{array}{l}22 / 62 \\
(35.48 \%)\end{array}$ & $\begin{array}{l}40 / 62 \\
(64.52 \%)\end{array}$ \\
\hline $\begin{array}{l}\text { Antigen Function } \\
\text { Testing }\end{array}$ & $\begin{array}{l}44 / 70 \\
(62.86 \%)\end{array}$ & $\begin{array}{l}26 / 70 \\
(37.14 \%)\end{array}$ & $\begin{array}{l}39 / 63 \\
(61.90 \%)\end{array}$ & $\begin{array}{l}24 / 63 \\
(38.10 \%)\end{array}$ & $\begin{array}{l}49 / 63 \\
(77.78 \%)\end{array}$ & $\begin{array}{l}14 / 63 \\
(22.22 \%)\end{array}$ \\
\hline $\begin{array}{l}\text { aCD3 Function } \\
\text { Testing }\end{array}$ & $\begin{array}{l}56 / 70 \\
(78.87 \%)\end{array}$ & $\begin{array}{l}14 / 70 \\
(20.0 \%)\end{array}$ & $\begin{array}{l}53 / 64 \\
(82.81 \%)\end{array}$ & $\begin{array}{l}11 / 64 \\
(17.19 \%)\end{array}$ & $\begin{array}{l}56 / 63 \\
(89.89 \%)\end{array}$ & $\begin{array}{l}7 / 63 \\
(11.11 \%)\end{array}$ \\
\hline
\end{tabular}

$\mathrm{n}=$ Number with specific response

$\mathrm{N}=$ Total number of responses

Table 4: Threshold parameters for giving MMR, Varicella, Rotavirus 


\begin{tabular}{|c|c|c|c|c|c|c|}
\hline & \multicolumn{2}{|c|}{ Responses $\mathrm{n} / \mathrm{N}(\%)$ MMR } & \multicolumn{2}{|c|}{ Responses $\mathrm{n} / \mathrm{N}(\%)$ Varicella } & \multicolumn{2}{|c|}{$\begin{array}{l}\text { Responses n/N(\%) } \\
\text { Rotavirus }\end{array}$} \\
\hline & $\begin{array}{l}\text { Give } \\
\text { when } \\
\text { normal }\end{array}$ & $\begin{array}{l}\text { Give when close to } \\
\text { normal }\end{array}$ & $\begin{array}{l}\text { Given } \\
\text { when } \\
\text { normal }\end{array}$ & $\begin{array}{l}\text { Give when close } \\
\text { to normal }\end{array}$ & $\begin{array}{l}\text { Give } \\
\text { when } \\
\text { normal }\end{array}$ & $\begin{array}{l}\text { Give } \\
\text { when } \\
\text { close to } \\
\text { normal }\end{array}$ \\
\hline \multirow{7}{*}{$\begin{array}{l}\text { CD4 } \\
\text { count }\end{array}$} & $20 / 60$ & $40 / 60(66.67 \%)$ & \multirow{7}{*}{$\begin{array}{l}17 / 53 \\
(32.08 \%)\end{array}$} & $36 / 53(67.92 \%)$ & \multirow{7}{*}{$\begin{array}{l}21 / 45 \\
(46.67 \%)\end{array}$} & $24 / 45$ \\
\hline & \multirow[t]{6}{*}{$(33.33 \%)$} & $\begin{array}{l}\S 2 / 40(5.0 \%) \geq \\
200\end{array}$ & & $\begin{array}{l}\S 1 / 36 \quad(2.78 \%) \\
\geq 200\end{array}$ & & \multirow{2}{*}{$\begin{array}{l}\S 9 / 24 \\
(37.5 \%) \\
\geq 400\end{array}$} \\
\hline & & $\begin{array}{l}\S 15 / 40(37.5 \%) \\
\geq 400\end{array}$ & & $\begin{array}{l}\S 1 / 36(2.78 \%) \\
\geq 250\end{array}$ & & \\
\hline & & $\begin{array}{l}\S 12 / 40(30.0 \%) \\
\geq 500\end{array}$ & & $\begin{array}{l}\S 14 / 36(38.8 \%) \\
\geq 400\end{array}$ & & $\begin{array}{l}\S 9 / 24 \\
(37.5 \%) \\
\geq 500\end{array}$ \\
\hline & & \multirow[t]{3}{*}{$\begin{array}{l}\text { §ु } 11 / 40(27.5 \%) \\
\text { Other }\end{array}$} & & $\begin{array}{l}\S 11 / 36 \\
(30.56 \%) \geq 500\end{array}$ & & \multirow{2}{*}{$\begin{array}{l}\$ 1 / 24 \\
(4.17 \%) \\
\geq 1000 \\
\text { or } \geq 40 \%\end{array}$} \\
\hline & & & & \multirow{2}{*}{$\begin{array}{l}\S 9 / 36(25.0 \%) \\
\text { Other }\end{array}$} & & \\
\hline & & & & & & $\begin{array}{l}\S 5 / 24 \\
\text { (20.83\%) } \\
\text { Other }\end{array}$ \\
\hline \multirow[t]{6}{*}{$\begin{array}{l}\text { CD8 } \\
\text { count }\end{array}$} & \multirow{6}{*}{$\begin{array}{l}9 / 39 \\
(23.08 \%)\end{array}$} & $30 / 39(76.92 \%)$ & $10 / 37$ & $27 / 37(72.97 \%)$ & \multirow{6}{*}{$\begin{array}{l}15 / 34 \\
(44.11 \%)\end{array}$} & $\begin{array}{l}19 / 34 \\
(55.88 \%)\end{array}$ \\
\hline & & $\begin{array}{l}\$ 1 / 30(3.33 \%) \geq \\
100\end{array}$ & \multirow{5}{*}{$(27.03 \%)$} & $\begin{array}{l}\S 1 / 27(3.7 \%) \geq \\
100\end{array}$ & & \multirow{2}{*}{$\begin{array}{l}\$ 3 / 19 \\
(15.79 \%) \\
\geq 200\end{array}$} \\
\hline & & $\begin{array}{l}\S 3 / 30(10.0 \%) \geq \\
200\end{array}$ & & $\begin{array}{l}\S 3 / 27(11.1 \%) \geq \\
200\end{array}$ & & \\
\hline & & $\begin{array}{l}\S_{250} 9 / 30(30.0) \geq \\
\text {. }\end{array}$ & & $\begin{array}{l}\S 9 / 27(33.33 \%) \\
\geq 250\end{array}$ & & $\begin{array}{l}\S 4 / 19 \\
(21.05) \\
\geq 250\end{array}$ \\
\hline & & $\begin{array}{l}\S 12 / 30(40 \%) \geq \\
300\end{array}$ & & $\begin{array}{l}\S 10 / 27 \\
(37.04 \%) \geq 300\end{array}$ & & $\begin{array}{l}\S 8 / 19 \\
(42.12 \%) \\
\geq 300\end{array}$ \\
\hline & & $\begin{array}{l}\text { § } 5 / 39(16.67 \%) \\
\text { Other }\end{array}$ & & $\begin{array}{l}\S 4 / 27(14.81 \%) \\
\text { Other }\end{array}$ & & $\begin{array}{l}\text { \$ } 4 / 19 \\
(21.05 \%) \\
\text { Other }\end{array}$ \\
\hline \multirow{2}{*}{$\begin{array}{l}\text { Mitogen } \\
\text { Function } \\
\text { Testing }\end{array}$} & \multirow{2}{*}{$\begin{array}{l}44 / 53 \\
(83.02 \%)\end{array}$} & 9/53 (16.98\%) & \multirow{2}{*}{$\begin{array}{l}40 / 48 \\
(83.33 \%)\end{array}$} & $8 / 48(16.6 \%)$ & $37 / 40$ & \multirow{2}{*}{$\begin{array}{l}3 / 40 \\
(7.50 \%)\end{array}$} \\
\hline & & $\begin{array}{l}\S \text { Threshold } \\
\text { response ranged } \\
\text { from at least a } \\
\text { measurable } \\
\text { response to } 75 \% \\
\text { of control. }\end{array}$ & & $\begin{array}{l}\S \text { Threshold } \\
\text { response ranged } \\
\text { from at least a } \\
\text { measurable } \\
\text { response to } 75 \% \\
\text { of control. }\end{array}$ & $(92.5 \%)$ & \\
\hline
\end{tabular}


$\mathrm{n}=$ Number with specific response

$\mathrm{N}=$ Total number of responses

\section{Supplementary Files}

This is a list of supplementary files associated with this preprint. Click to download.

- Appendixl.docx 